\title{
DOS CLÁSSICOS AOS HEREGES: KEYNES E A ECONOMIA DE SEU TEMPO*
}

\author{
Rogério Arthmar
}

\author{
Michael Emmett Brady ${ }^{* * *}$
}

\section{Alexandre O. T. Salles ${ }^{* * *}$}

\begin{abstract}
RESUMO O artigo trata da posição teórica de Keynes relativamente à economia clássica e à abordagem denominada herética. A primeira seção resgata os traços distintivos das escolas clássica e neoclássica segundo a demarcação proposta por Keynes, bem como as críticas por ele dirigidas às principais teses defendidas por essas linhagens teóricas. A seguir, retoma-se a sua avaliação dos argumentos subconsumistas, indicando-se os seus pontos de convergência e distanciamento dessa visão econômica. Na continuação, apresentam-se as interpretações neoclássicas ao problema da demanda, comentando-se a relação da obra de Keynes com a tradição marshalliana. A última seção avalia a teoria neoclássica do produto real sob condições cíclicas e introduz a versão de Keynes para o equilíbrio agregado definido pelas propensões a gastar e a investir, além de indicar o componente de fragilidade da leitura marshalliana de sua estrutura teórica. Por fim, comenta-se a contribuição de Keynes ao conhecimento econômico da época perante a escola clássica e os hereges.
\end{abstract}

Palavras-chave: demanda efetiva; ciclos econômicos; equilíbrio agregado; economia keynesiana

Código JEL: B22; B31; E12

* Artigo enviado em 5 de outubro de 2008 e aprovado em 16 de julho de 2010.

** Doutor em Economia pela Universidade de São Paulo, USP. Mestre em Economia pela UFRGS, e-mail: arthmar.vix@gmail.com

*** $\mathrm{PhD}$ in Economics pela University of California Riverside, Department of Operations Management, California State University, e-mail: mandbrady@juno.com

$* * * * \mathrm{PhD}$ in Economics pela University of Hertfordshire. Mestre em Economia pela UFF, e-mail: aotsalles@gmail.com 


\section{FROM THE CLASSICAL TO THE HERECTICS:}

\section{KEYNES AND THE ECONOMICS OF HIS DAY}

ABSTRACT This paper deals with Keynes' theoretical stance toward both the classical economics and the so-called heretic approach. The first section delineates the distinctive traces of the classical and the neoclassical schools according to Keynes' criteria, as well as his critique of the main theses advanced by these theoretical lineages. Next, it presents his evaluation of the main underconsumptionist arguments, indicating his points of convergence to and contention with this economic vision. After that, the neoclassical analyses of the demand puzzle are retrieved, along with some observations on the relation of Keynes' work with the marshallian tradition. The last section evaluates the neoclassical theory of aggregate output under cyclical conditions and introduces Keynes' version for the aggregate equilibrium defined from the propensities to spend and to invest, pointing out also the fragility of the marshallian interpretation of his theoretical structure. Eventually, it comments on Keynes' contribution to the economic knowledge of the time with regard to the classical and the heretic schools.

Key words: effective demand; business cycles; aggregate equilibrium; Keynesian economics 


\section{INTRODUÇÃO}

Em conferência proferida durante a inauguração do Cambridge Economic Club, em 1896, Alfred Marshall, então no ápice de sua carreira, convocava a nova geração de economistas a evitar a tentação de analisar uma economia idealizada e, ao invés disso, estudar as coisas como elas de fato se apresentavam aos filósofos: "Não devemos conceber um mundo irreal que pode, ou deve ser, e visualizar esquemas para ele [...]. Nosso compromisso maior como economistas é elaborar um catálogo racional do mundo como ele é" (1925 [1896], p. 302-303). Essas não apenas eram palavras sábias, mas também proféticas. Quarenta anos mais tarde, um antigo pupilo de Marshall julgaria sua missão levar a termo o comando do mestre. Na verdade, enquanto os capítulos do livro The General Theory of Employment, Interest and Money (GT) assumiam contornos mais precisos na mente de Keynes, fortalecia-se a sua convicção de que a teoria econômica de seu tempo, inclusive aquela esposada por seu aclamado mentor, não se coadunava à realidade existente. Em uma nota datada de 1933, Keynes descreve a visão ortodoxa do equilíbrio como uma construção abstrata ultrapassada, obcecada com o poder metafísico da poupança na criação de riqueza e, por conseguinte, incapaz de perceber o imenso custo envolvido no desprezo à importância dos gastos. A respeito de tal situação, ele lamentava igualmente a inabilidade de seus colegas em prover conselhos úteis a um público cada vez mais incrédulo: "A impotência [dos economistas] para tanto e as profundas suspeitas sobre sua capacidade nascidas de suas tentativas malogradas encontram-se, assim entendo, na base da explicação de seu baixo conceito como especialistas em assuntos práticos" (JMK, XIII, 1987, p. 406).

A inépcia do pensamento ortodoxo em lidar com os assuntos prementes da época, a saber, a retração dos mercados e o desemprego maciço, encontrava-se na raiz do propósito de Keynes em guiar a ciência econômica em uma nova direção. Com essa perspectiva, o presente artigo revisa, por meio de uma abordagem histórico-comparativa, sua posição sobre a teoria econômica de seu tempo. Para tanto, a primeira seção recapitula a delimitação de Keynes para as escolas clássica e neoclássica, bem como suas críticas a cada uma dessas duas correntes de pensamento. A seção seguinte retoma sua interpretação das ideias subconsumistas, examinando em que medida ele se distanciou das propostas então correntes de ampliação do consumo. 
A seguir, apresenta-se a maneira como as formulações pioneiras do ciclo econômico avançadas por Marshall e Wicksell tratavam a demanda em suas análises das flutuações periódicas do capitalismo, bem como os possíveis vínculos da teoria de Keynes com a tradição marshalliana. Na última seção, verifica-se como os economistas neoclássicos, nas figuras de Robertson, Pigou e Cassel, explicavam os ciclos econômicos, introduzindo-se o princípio da demanda efetiva a partir dos conceitos de propensão a gastar e a investir, refutando-se ainda, por fim, a releitura marshalliana da GT. Nas considerações finais, procura-se situar a contribuição de Keynes ao saber econômico do período em face do legado dos pensadores clássicos e hereges.

\section{A VISÃO CLÁSSICA dO PRODUTO E DA TAXA DE JUROS}

Qualquer tentativa de sistematização do pensamento de Keynes sobre a teoria econômica de seu tempo, particularmente em relação ao que se pode denominar a doutrina dominante nos anos do entreguerras, enfrenta de imediato dois obstáculos significativos. Inicialmente, avulta a dificuldade ligada ao hábito peculiar a Keynes de indicar pela expressão escola clássica um vasto conjunto de autores cobrindo desde os primórdios do século XIX até a década de 1930. Logo na abertura da GT consta a bem conhecida nota de rodapé reproduzida a seguir: "Acostumei-me, talvez perpetrando um solecismo, a incluir na 'escola clássica' os seguidores de Ricardo, ou seja, os que adotaram e aperfeiçoaram sua teoria, compreendendo (por exemplo) J. S. Mill, Marshall, Edgeworth e o prof. Pigou” (GT, 1964 [1936], p. 3, itálicos no original; cf. também JMK, XIV, 1973, p. 112-113). É inegável que, ao assim proceder, Keynes abrigou sob um mesmo teto todo um contingente de autores com larga heterogeneidade de posicionamentos teóricos e metodológicos sobre a ciência econômica, de resto já devidamente tratada na literatura moderna. ${ }^{1}$ Não fosse isso o bastante, ele haveria de reconhecer, ainda que ocasionalmente, a existência de autores contemporâneos vinculados à corrente neoclássica, como veremos adiante, designação utilizada em duas passagens do capítulo 14 da GT sobre a concepção ortodoxa da taxa de juros (GT, 1964 [1936], p. 177 e 183)..$^{2}$

O segundo empecilho no caminho de uma síntese da postura de Keynes no que tange à teoria econômica de sua época relaciona-se ao fato de haver 
ele aberto inúmeros flancos de ataque à escola clássica, muitos deles inseridos de forma isolada nos mais variados contextos. A isso se soma a circunstância agravante, lembrada seguidamente pelo próprio Keynes, de diversos pressupostos por ele atribuídos ao pensamento ortodoxo jamais terem sido admitidos de forma explícita nas obras dos economistas arrolados como representantes dessa linhagem teórica. Excetuando-se, então, os capítulos 2 e 14 da GT, em que a visão clássica do mercado de trabalho e da taxa de juros, respectivamente, recebem tratamento mais pormenorizado, o mesmo não pode ser dito dos demais artigos, conferências, rascunhos, correspondências e outros escritos ocasionais nos quais ele faz referência ao assunto. ${ }^{3}$

Mesmo levando-se em conta a diversidade de ângulos explorados por Keynes ao contemplar criticamente a escola clássica, é possível, não obstante, breve delineamento de sua visão geral do tema. Assim, conforme assinalado na GT, a concepção econômica tradicional estaria segmentada em dois grandes compartimentos: o primeiro, envolvendo a Teoria do Valor e cobrindo o campo da economia real, dedicado à determinação dos preços relativos das mercadorias por suas respectivas condições de oferta e demanda, enquanto o segundo compreenderia a Teoria Monetária, em que os preços absolutos estariam definidos pela quantidade de moeda, por sua velocidade de circulação e por outros fatores subsidiários, como entesouramento, inflação etc. (GT, 1964 [1936], p. 293-294).

Tomando-se essa divisão como ponto de partida, destaca-se, então, a persistência de Keynes na crítica àquilo que entendia ele constituir-se o traço mais contundente da teoria econômica de seu tempo, isto é, a noção de prevalência do produto de pleno emprego (JMK, XIII, 1987, p. 541; GT, 1964 [1936], p. 26, 33, 191 e 284; e JMK, XIV, 1973, p. 26, 58 e 106, passim). Esse aspecto do pensamento ortodoxo, em sua forma de ver, apresentava-se como corolário de três linhas de argumentação distintas no domínio da economia real. A primeira delas estaria ligada ao apego dos economistas clássicos à Lei de Say, sustentáculo da crença na igualdade entre poupança e investimento, ou, no linguajar da GT, entre os preços de oferta e de demanda do produto agregado, configurando o célebre "axioma das paralelas" (GT, 1964 [1936], p. 21, e JMK, XIV, p. 372). Já o segundo argumento compreendia a abordagem idealizada por Jevons, Marshall e Pigou, de acordo com a qual a inexistência de desemprego involuntário decorreria dos postulados de igualdade 
do salário com o produto marginal do trabalho, bem como da utilidade dos salários com a desutilidade marginal do volume de emprego, conformando ambos, respectivamente, as curvas de demanda e de oferta de mão de obra. Em tais condições, específicas a um mercado de trabalho competitivo, eventual presença de trabalhadores desempregados viria acompanhada por negociações conducentes a reduções nos salários reais até que se alcançasse o equilíbrio com o pleno emprego (GT, 1964 [1936], cap. 2, e JMK, XIV, 1973, p. 25-26). Conjugando-se, então, o axioma das paralelas com um mercado de trabalho inteiramente flexível no bojo da doutrina clássica, Keynes chega ao seguinte resultado teórico: "Isto [a Lei de Say] quer dizer que a demanda efetiva, em vez de ter um único valor de equilíbrio, comporta uma série infinita de valores, todos igualmente admissíveis, e que o volume de emprego é indeterminado, salvo na medida em que a desutilidade marginal do trabalho lhe fixe um limite superior" (GT, 1964 [1936], p. 26).

Mas a proposição sustentando o uso irrestrito dos fatores produtivos, com consequente elasticidade nula do produto, estaria apoiada, também, em um terceiro argumento de natureza real: a abordagem clássica da taxa de juros. Keynes, nesse ponto, elege Marshall, Walras e Cassel como principais representantes do conceito de que a taxa de juros funcionaria como variável de ajuste entre as curvas de oferta de abstinência e de demanda por capital, de modo equivalente à ação dos preços nos mercados reais de bens, derivando daí a igualdade entre poupança e investimento no plano agregado. Havendo um deslocamento para a direita na curva de eficiência marginal do capital, por exemplo, a taxa de juros viria a se elevar de maneira a estimular a poupança, além de amortecer parcialmente o ímpeto da procura de recursos para novas inversões, até se alcançar o ponto em que as duas variáveis coincidissem (GT, 1964 [1936], p. 175-177; JMK, XIV, 1973, p. 101-108).

Além das forças mencionadas, um fator de ordem estritamente monetária trabalharia igualmente pela preservação do pleno emprego. Ao assumir o futuro como inteiramente calculável e desprovido de incertezas, a escola clássica, de acordo com Keynes, excluíra a possibilidade de entesouramento e reconhecera unicamente a demanda por moeda para transações. A taxa de juros, conforme a Teoria Quantitativa, seria independente da oferta monetária a longo prazo. Em uma economia com salários plenamente flexíveis, no entanto, qualquer redução na disponibilidade de moeda redundaria em uma 
diminuição imediata da demanda efetiva e, portanto, em certo desemprego temporário. A queda subsequente nos salários e nos preços atenuaria a procura de moeda para transações, reduzindo a taxa de juros e estimulando as inversões em capital até o restabelecimento da ocupação plena dos fatores de produção, concatenação teórica designada na literatura como efeito Keynes (GT, 1964 [1936], p. 262-266; JMK, XIV, 1973, p. 119 e 490). ${ }^{4}$ Ou, nos termos constantes no ensaio The theory of the rate of interest (1937):

A teoria ortodoxa, por outro lado, preocupa-se com um mundo simplificado onde prevalece sempre o pleno emprego e onde a dúvida e as flutuações na confiança estão excluídas, não havendo ocasião para a posse de saldos inativos, situando-se os preços constantemente a um nível que, satisfazendo meramente o motivo de transações, sem deixar resíduo livre para ser absorvido pelos motivos de precaução ou especulação, faz o estoque total de moeda valer uma taxa de juros igual à eficiência marginal do capital que corresponde ao pleno emprego (JMK, XIV, 1973, p. 107).

Apesar do uso recorrente do adjetivo clássico ao longo da GT, Keynes, ao tratar da taxa de juros, reconhece a existência de um grupo de autores, abarcando Hawtrey, Robertson, Hayek e até a si mesmo ao tempo do TM, para quem as divergências entre a poupança e o investimento representariam não apenas evento factível, mas, acima de tudo, deflagrador dos ciclos econômicos. Na teoria de tais economistas neoclássicos, assinala Keynes, a condição de igualdade entre poupança e investimento poderia ser perturbada pela interferência indevida do crédito que, ao estabilizar a taxa de juros "monetária" em patamar inferior ao da taxa "normal" definida pela interseção entre as curvas de oferta de abstinência e de procura de capital, sancionaria artificialmente certo volume de investimentos desprovido de poupança prévia correspondente. Dessa discrepância brotariam, então, todas as dificuldades usuais associadas aos ciclos econômicos. Robertson e Hayek, por exemplo, enxergavam no fluxo acrescido de despesas de capital a causa primária de um acréscimo generalizado nos preços que faria por vitimar os detentores de rendimentos fixos, impondo-lhes uma privação forçada capaz de igualar, adiante, a poupança agregada à magnitude ampliada dos investimentos. Como descrito na GT:

Essa última escola [neoclássica] inferiu haver duas fontes de oferta para atender a curva de demanda por investimento, a saber, a poupança propria- 
mente dita, tratada pela escola clássica, mais as somas disponibilizadas por qualquer aumento na oferta de moeda (essas últimas compensadas por alguma espécie de confisco sobre o público denominado "poupança forçada" ou algo semelhante). Isso se reflete na ideia de existência de uma taxa de juros de equilíbrio "natural" ou "neutra", qual seja, aquela taxa de juros capaz de igualar o investimento com a poupança clássica sem nenhum tipo de "poupança forçada" (GT, 1964 [1936], p. 183).

Esclarecidos esses aspectos demarcatórios das escolas clássica e neoclássica na perspectiva de Keynes, é possível, então, contemplar de relance suas críticas à ortodoxia predominante à época. Inicialmente, a segmentação usual da teoria econômica em uma esfera real e em outra monetária careceria de fundamento. Ele sugere, ao invés disso, a divisão da ciência entre uma Teoria da Firma Individual, versando sobre a distribuição de uma dada disponibilidade de recursos produtivos entre diferentes usos, e uma Teoria do Produto e do Emprego, direcionada ao tratamento desses temas fundamentais no âmbito de uma economia essencialmente monetária ( GT, 1964 [1936], p. 293). Já a Lei de Say, por sua vez, haveria desconsiderado o fato crucial, definidor do princípio da demanda efetiva, de que os gastos em investimento nem sempre se acomodariam espontaneamente ao lapso na demanda deixado em aberto por uma propensão a consumir inferior à unidade (JMK, XIII, 1987, p. 422-423, 457-459; GT, 1964 [1936], cap. 3). Isso porque o futuro não seria inteiramente calculável, como imaginavam os clássicos, de sorte que as inversões privadas estariam sujeitas a grandes sobressaltos devido às reviravoltas frequentes no estado de confiança que, em última instância, governaria as expectativas de longo prazo relativas à aquisição de novos bens de capital (GT, 1964 [1936], cap. 12).

Quanto à concepção clássica sobre o funcionamento do mercado de trabalho, Keynes adverte que os acordos salariais seriam estipulados em termos pecuniários, restando impossível aos trabalhadores, por si só, rebaixarem o salário real mediante reduções nos seus rendimentos nominais. ${ }^{5}$ Além disso, seria preciso levar em conta a oposição das organizações sindicais a cortes na remuneração de certos grupos de trabalhadores por envolver uma queda nos vencimentos efetivos comparativamente a outras categorias assalariadas. O mesmo, contudo, não seria válido na hipótese de um declínio nos salários reais oriundo de uma elevação nos preços, pois os desempregados 
ainda assim estariam dispostos a serem contratados, apesar do aumento no custo de vida. De qualquer sorte, Keynes mantém que o esquema analítico subjacente à hipótese de um mercado de trabalho competitivo se mostrar inútil em face da realidade da época, assolada pelo desemprego em grande escala (GT, 1964 [1936], p. 4-18).

Disso tudo resultaria, então, o caráter absurdo (nonsense) da teoria clássica da taxa de juros, pois os pretensos determinantes dessa variável crucial, isto é, as curvas de oferta de abstinência e de procura de capital, não seriam independentes entre si como idealizado pelos pensadores clássicos. Ao contrário, como insistiria Keynes sem descanso, a menor modificação em qualquer uma delas implicaria alteração na renda agregada assumida como parâmetro de ambas as funções, inviabilizando, por conseguinte, o cálculo da taxa de juros de equilíbrio. Daí, portanto, que a própria definição dessas curvas fosse qualificada por ele como irremediavelmente falsa (bogus), pois, no caso de uma elevação na taxa de juros, o impacto seria idêntico tanto nos gastos de capital quanto na poupança, já que esta última terminaria reduzida na mesma medida do investimento por conta da variação na renda agregada. Como expressou Keynes de modo peremptório a Harrod, em agosto de 1935: "Em verdade, não existe algo como essas duas curvas [...] Sem menção à preferência pela liquidez, a posição de equilíbrio é completamente indeterminada e qualquer método que pretenda chegar à taxa de juros sem a preferência pela liquidez, como o clássico, está fadado a se envolver numa lógica circular no pior sentido da palavra" (JMK, XIII, 1987, p. 551). ${ }^{6}$ Quanto às teses dos autores neoclássicos, aplicar-se-ia o mesmo argumento, aduzindo-se ainda que a sugestão de existência de uma privação forçada consistiria, para Keynes, em mera ilusão de óptica, haja vista que o investimento abastecido pelo crédito daria origem a uma poupança de igual magnitude, realizada de forma livre pelos indivíduos e tão legítima quanto aquela já existente (GT, 1964 [1936], p. 81-85). ${ }^{7}$

Por fim, a aceitação incondicional da vigência do produto de pleno emprego por parte dos autores clássicos haveria engendrado ainda, na percepção de Keynes, duas outras consequências funestas para o saber econômico. A primeira delas residiria no virtual desaparecimento do conceito de demanda efetiva da literatura ortodoxa. "A ideia de que podemos negligenciar a função de demanda agregada, sem outras considerações, é fundamental à 
economia ricardiana, base do que nos tem sido ensinado há mais de um século" (GT, 1964 [1936], p. 32). Essa situação deplorável, em sua forma de ver, resultara do caráter austero das prescrições clássicas de política econômica, da elegância da estrutura teórica ricardiana, da autoridade emanada da noção de serem as injustiças sociais percalços inevitáveis no curso do progresso material e, por fim, do louvor à livre iniciativa que catalisara o suporte das forças sociais dominantes no capitalismo. $\mathrm{O}$ abandono da discussão sobre o enigma dos mercados por parte dos adeptos da escola clássica viria acompanhado, também, por outra sequela trágica da conviç̧ão pertinaz no pleno emprego: a incapacidade incontornável de concederem eles tratamento adequado aos graves problemas das nações afluentes durante os anos do entreguerras. A ciência econômica, ao invés de servir à promoção da riqueza e do bem-estar, convertera-se, assim, de acordo com Keynes, em verdadeiro entrave a um estado de maior prosperidade.

Embora a doutrina em si tenha permanecido sem questionamento pelos economistas ortodoxos até recentemente, sua notória inadequação para os propósitos de predição científica comprometeu seriamente, no curso do tempo, o prestígio de seus praticantes [...]. Pode bem ser que a teoria clássica represente a maneira pretendida que a nossa economia se comporte. Mas assumir que assim o seja na realidade é presumir que nossas dificuldades não mais existam (GT, 1936 [1964], p. 33-34).

Tendo então coberto de forma panorâmica a visão de Keynes relativamente à delimitação das escolas clássica e neoclássica, bem como as críticas por ele endereçadas à estrutura teórica elaborada por essa vertente de pensamento econômico, vejamos o tratamento por ele dispensado aos autores identificados como dissidentes.

\section{OS HEREGES, A RELEVÂNCIA DO CONSUMO E O SENSO COMUM}

Entre os meses de julho e novembro de 1931, Keynes manteve profícuo intercâmbio com John Hobson, conhecido teórico subconsumista britânico e crítico do imperialismo. Transcorrido logo após a publicação do TM, o episódio encontra Keynes ainda convicto da independência recíproca entre as funções poupança e investimento, bem como do poder de ambas de determinar a taxa de juros (JMK, XIII, 1987, p. 330-336). Logo em sua primeira carta, Keynes contesta uma proposição de Hobson insinuando a possibili- 
dade de acúmulo de uma massa de capital real como contrapartida de certo volume de poupança não investida. Tal cenário resultaria implausível, afirma Keynes, porque eventual excesso de poupança acarretaria queda nos preços dos artigos de consumo, beneficiando os compradores e prejudicando, portanto, os produtores, que terminariam por transferir parte de seus ativos aos poupadores. Hobson, reticente, responde que um ganho de produtividade na fabricação de bens essenciais poderia reduzir os seus preços sem um acréscimo proporcional no consumo. Isso geraria uma poupança adicional que reverteria em perdas para os produtores, restrição na oferta, desemprego e, finalmente, capital ocioso. A origem disso tudo, esclarece ele, estaria radicada na incapacidade do consumo de acompanhar o aumento na produção, na concentração de renda favorável à poupança e na retenção de lucros pelas grandes companhias. Keynes, de sua parte, contrapõe que o problema não se localizaria unicamente em uma insuficiência do consumo, mas na falha da taxa de juros em cair como reflexo da expansão na poupança. Se assim sucedesse, o preço dos bens de consumo intensivos em capital diminuiria, ampliando as suas vendas e estimulando as inversões no setor. Em sua última carta, Hobson mostra-se cauteloso em relação ao raciocínio de Keynes e escreve, antecipando a visão futura de seu interlocutor: "Que a taxa de juros desempenhe papel importante algumas vezes, estou pronto a admitir, mas a eficiência de sua ação como estímulo ou freio suscita muitas dúvidas. Em certas situações de expansão ou recessão, seu efeito parece frágil e suspeito" (JMK, XIII, 1987, p. 335).

Algum tempo depois, na locução radiofônica Poverty in plenty (1934), Keynes se revelaria mais receptivo às ideias de Hobson e outros cépticos, já em linha com a posição que viria a adotar sobre o tema na GT. A preleção estrutura-se em torno da divisão do pensamento econômico do período em dois grandes grupos. De um lado, perfilavam-se os defensores da capacidade de auto-ajustamento do sistema econômico a longo prazo, ainda que refreada por certas defasagens, atritos e interferências externas. De outro, congregavam-se os ditos incrédulos, empenhados em denunciar as lacunas estruturais na demanda como impedimento maior ao pleno desempenho produtivo da economia. ${ }^{8}$ Keynes, apesar de divergir parcialmente da leitura teórica dos hereges, louva, não obstante, o senso prático e a experiência de mundo partilhada por eles, incluindo aí a si próprio: 
Aqueles do meu lado do golfo, a quem ousei proclamar como meio-certos, meio-errados, perceberam isso [a debilidade da doutrina clássica] e concluíram que o único remédio possível seria modificar a distribuição da riqueza e nossos hábitos de modo a aumentar a propensão a gastarmos nossas rendas em consumo corrente. Concordo com eles que isso seria um remédio. Mas discordo deles quando vão além e defendem ser esse o único remédio. Pois existe uma alternativa, notadamente, aumentar a oferta de bens de capital pela redução da taxa de juros e outros meios (JMK, XIII, 1987, p. 490).

Passando então a Malthus, é interessante resgatar algumas considerações sobre esse notório dissidente do pensamento clássico alinhavadas nos Essays in Biography $(E B, 1933)$. No livro, Keynes ressalta a sólida amizade do reverendo com Ricardo e, a seguir, recupera o extenso debate entre ambos sobre o problema dos mercados. Nesse ponto, posiciona cada um deles em campos opostos, similares aos que definiria adiante em sua contenda com a economia clássica: "Ricardo investiga a teoria da distribuição do produto em condições de equilíbrio e Malthus preocupa-se com os determinantes do volume de produção no cotidiano do mundo real” (EB, 1951 [1933], p. 115-116). Keynes reproduz, então, longos excertos da correspondência entre os dois autores, salientando a preocupação exclusiva de Ricardo com as tendências de longo prazo em detrimento das dificuldades reais da economia, descartadas como transitórias, bem como a resposta de Malthus reafirmando a importância das flutuações recursivas vivenciadas pelo mundo dos negócios, especialmente dos momentos adversos marcados pelo desvanecimento dos escoadouros à produção. Dessa diferença não apenas de concepções teóricas, mas também de abordagens em relação ao objeto da controvérsia, Keynes conclui:

Não se consegue emergir da leitura de tal correspondência sem o sentimento de que a total obliteração da linha de raciocínio de Malthus e o completo domínio de Ricardo pelo período de uma centena de anos tenha sido um desastre para o progresso da economia. Repetidamente, nessas cartas, Malthus fala em termos do senso comum, num argumento cuja força Ricardo, com sua cabeça nas nuvens, falha inteiramente em compreender (EB, 1951 [1933], p. 117).

As referências a Malthus na GT restringem-se à inclusão de partes de suas cartas a Ricardo e pouco adicionam, portanto, ao material apresentado nos 
Essays (GT, 1964 [1936], p. 362-364). Keynes voltaria a comentar algumas ideias malthusianas no artigo "Some economic consequences of a declining population" Keynes (1937), em que as preocupações do jovem pregador com os malefícios de uma população crescente cedem lugar aos problemas associados ao desemprego oriundos da debilidade na demanda efetiva, alardeados sem sucesso por Malthus em sua idade madura. Keynes, ao discorrer sobre os efeitos de uma população regressiva, sugere como providências voltadas à manutenção da prosperidade uma melhor distribuição de renda, visando a reforçar o consumo, aliada a uma política de compressão da taxa de juros destinada à preservação do investimento (JMK, XIV, 1973, p. 131-133).

A avaliação mais consistente das ideias dos autores intitulados hereges, contudo, seria articulada por Keynes na GT, especialmente nos capítulos finais sobre o ciclo econômico e o mercantilismo. Na primeira seção, em que trata das teses subconsumistas, ele se declara alinhado com a visão geral que lhes servia de fundamento, advertindo, porém, que a prescrição de acréscimo no consumo somente seria apropriada em uma situação na qual não mais fosse possível expandir o estoque de capital. Assim, a política de revigoramento da propensão a consumir estaria justificada apenas na medida em que a iniciativa viesse a abrandar a necessidade de um investimento crescente para garantir o pleno emprego em sociedades abastadas (GT, 1964 [1936], p. 324-326). Essa interpretação do problema econômico, comenta Keynes no capítulo seguinte, encontraria sua origem remota no pensamento mercantilista, cujos maiores expoentes, homens práticos, haveriam se confrontado com os embaraços ocasionados pela tendência secular da inclinação a poupar exceder o estímulo ao investimento. Naqueles tempos pretéritos, prossegue Keynes, os novos empreendimentos viam-se cercados por riscos e perigos de toda ordem e a eficiência do capital, portanto, se apresentava precária. A proposta mercantilista de obtenção de um saldo comercial positivo, por isso, carregaria uma centelha de verdade ao revestir-se de dupla importância, de um lado ampliando a demanda efetiva e, de outro, expandindo a circulação monetária de modo a facilitar a queda na taxa de juros. Embora medidas protecionistas fossem usualmente acompanhadas por retaliação equivalente em outros países, ao mesmo tempo em que o barateamento dos juros poderia levar à evasão de capitais, Keynes qualifica a política mercantilista como superior àquela professada pelos economistas clássicos: 
Não obstante, como contribuição à arte de condução dos assuntos do Estado, preocupada com o sistema econômico como um todo e com a promoção do emprego ótimo de todos os recursos do sistema, os métodos dos antigos pioneiros do pensamento econômico nos séculos XVI e XVII podem ter alcançado os fragmentos de uma sabedoria prática que as abstrações irrealistas de Ricardo primeiramente omitiram e, após, obliteraram (GT, 1964 [1936], p. 340).

A apreensão permanente dos autores da época com as condições da demanda, manifesta de forma contumaz no assim denominado "medo das mercadorias" ( fear of goods), ${ }^{9}$ assumia, não raramente, como no caso de Mandeville, a forma de exaltação dos gastos suntuários e de condenação da parcimônia como métodos mais seguros de encorajar os negócios e o emprego. A reprovação de tal discurso pelos moralistas da época, para quem a virtude compreenderia unicamente abstenção e renúncia, sufocara o pensamento dissidente até o surgimento de Malthus, o primeiro, na avaliação de Keynes, a haver ancorado o desemprego em uma deficiência crônica da demanda sob o capitalismo. O expediente dos sucessores de Stuart Mill, último clássico a debruçar-se sobre o tema, teria consistido, mais precisamente, em remover a questão do corpo do saber econômico do que em fornecer-lhe solução analítica adequada. Hobson e Mummery, ao final do século XIX, em The Phisiology of Industry (1889), haveriam retomado o ataque à ortodoxia econômica apoiados no senso prático característico dos autores heréticos, mas recorrendo a uma base teórica demasiadamente frágil. Pois, como aponta Keynes, se eles acertaram ao ressaltar a dependência do investimento em relação à demanda prospectiva de consumo, laboraram em erro, contudo, ao assumirem a poupança como automaticamente convertida em novo capital. Se assim ocorresse de fato, sequer existiria um problema de demanda, como replicavam argutamente os defensores da Lei de Say. A dificuldade maior, contudo, acresce Keynes, decorria da circunstância de ambos os autores ignorarem a dependência da escala do investimento em relação à taxa de juros, porquanto a poupança agora, em contraste direto com a posição por ele esposada logo após o TM, seria de todo redundante em uma economia regida pelo princípio da demanda efetiva:

Sua tese, porém, não chegou a ser completa, essencialmente por não possuir uma teoria independente da taxa de juros, resultando que Hobson depositou 
demasiada ênfase [...] no subconsumo conduzindo ao sobreinvestimento, no sentido de investimento lucrativo, ao invés de explicar que a debilidade da propensão a consumir ajuda a causar desemprego por exigir e não receber o acompanhamento de um volume compensatório de novo investimento que, embora possa ocorrer temporariamente devido a erros de otimismo, é geralmente impedido de ter lugar pelo fato de o lucro prospectivo cair abaixo do patamar definido pela taxa de juros (GT, 1964 [1936], p. 370, grifo do original).

Keynes, portanto, em sua avaliação das propostas teóricas contrárias à doutrina ortodoxa, das quais dizia considerar-se próximo, não deixou de apontar as incoerências de tais interpretações do capitalismo, enaltecendo, todavia, o senso comum de seus proponentes. Na próxima seção, procura-se então avaliar até que ponto as críticas de Keynes à economia de seu tempo apresentavam-se pertinentes.

\section{A DEMANDA NA TEORIA NEOCLÁSSICA:} KEYNES E A TRADIÇÃO MARSHALLIANA ${ }^{10}$

Embora seja bem estabelecido que Ricardo e mesmo Say adotaram, com efeito, uma versão suave do postulado de conversão automática da poupança em investimento, reconhecendo inclusive algumas possibilidades de a demanda efetiva situar-se aquém da oferta agregada (vejam-se Becker e Baumol, 1960; Sowell, 1972), a condenação dos antigos clássicos proferida por Keynes pode ser aceita, sem discussão ulterior, como essencialmente acurada. ${ }^{11}$ Eles, afinal, apenas pretendiam demonstrar que uma economia capitalista progressiva possuiria a capacidade de abrir naturalmente os seus próprios canais de venda para a produção carreada ao mercado, dispensando, portanto, qualquer gênero de despesa improdutiva vinculada aos proprietários fundiários ou ao estado absolutista remanescentes da sociedade feudal. Ricardo, de sua parte, admitia unicamente a elevação dos salários como força incontornável de constrição da taxa de lucro. Se a rentabilidade dos capitais porventura declinasse em virtude de algum suposto lapso na demanda total da economia, o transtorno, segundo ele, seria tão somente passageiro. A redução na taxa de lucro não deixaria de desestimular o investimento, motivo original da acumulação excessiva, induzindo automaticamente as pessoas a pouparem menos e a consumirem mais (Blaug, 1958, p. 89-93; Corry, 1962, p. 32-37). 
Por outro lado, se o princípio da demanda efetiva aproximou Keynes dos hereges, ao mesmo tempo alçou-o bem acima deles. Autores como Malthus, Blake ou Sismondi, ao chamarem a atenção aos efeitos perniciosos da poupança excessiva, notadamente a saturação dos mercados, concebiam como única terapia à ameaça permanente de estagnação econômica o gasto improdutivo dos proprietários de terras e do governo ou então a expansão no consumo dos trabalhadores (vejam-se Sowell, 1972, caps. 2-4; Bleaney, 1976, caps. 2-5, 8 e 10). Movia-os a preocupação genuína com a circunstância intrigante de a poupança oriunda de uma diminuição no consumo dos capitalistas, ao ser convertida em investimento na forma de bens de subsistência à disposição dos trabalhadores, gerar apenas como procura adicional os salários pagos, restando inexplicada a origem da demanda capaz de absorver a produção restante e, portanto, de materializar os lucros latentes na operação (cf. Bleaney, 1976, p. 53-54). Keynes, porém, tinha plena consciência de sua afinidade, bem como de sua distância, com os dissidentes da ortodoxia. Para ele, os tempos ruins nunca adviriam de uma expansão prévia desenfreada do investimento, como usualmente indicado pelos hereges (que nisso se aproximavam dos autores neoclássicos), mas exatamente da situação contrária. O caráter progressista da visão de Keynes fica manifesto em seu comentário sobre o papel do capital durante a palestra Poverty and plenty. Para os dissidentes, a expansão do consumo estaria justificada não apenas por ampliar a demanda, mas também por reduzir a oferta de bens via a contração nos investimentos, armadilha teórica na qual Keynes em momento algum se deixou apanhar:

Assim, no presente, é importante manter um balanço cuidadoso entre os estímulos ao consumo e ao investimento. O bem-estar econômico e social será aumentado no longo prazo por uma política voltada a tornar os bens de capital tão abundantes que a recompensa por possuí-los decline a um patamar tão modesto que não mais represente um fardo sério para qualquer um. O rumo correto consiste em nos livrarmos da escassez de bens de capital a qual nos livrará ao mesmo tempo da maior parte dos males do capitalismo [...] (JMK, XIII, 1987, p. 489-490).

Tendo avaliado brevemente a estatura de Keynes perante as principais vertentes de pensamento econômico do período, é oportuno averiguar mais detidamente a sua afirmação de que os clássicos, em seu sentido amplo, des- 
consideraram a demanda efetiva em suas análises da economia agregada. Se, como indicado, a acusação pode ser julgada pertinente no caso dos antigos ricardianos, ela já não pode ser acolhida tão rapidamente no tocante aos autores neoclássicos da época. Quando a questão passou a envolver nomes do porte de Marshall e Pigou, fortes reações surgiriam inevitavelmente, mesmo antes de a GT alcançar o domínio público. Robertson, por exemplo, não se mostrou nem um pouco propenso a aceitar a tentativa de Keynes de estender o manto clássico sobre os ombros de distintos economistas contemporâneos, particularmente os de Cambridge. E, a respeito disso, manifestou-se incisivamente em seus comentários sobre os esboços da GT:

Não me agrada em nada seu tratamento do que você chama de economia clássica e eu denomino economistas modernos! [...] No que consistem as descrições do ciclo de crédito apresentadas por Marshall nos seus Principles p. 709-11 e em $M$ (oney) C(redit) and C(ommerce) p. 249-51 do que estudos sobre as flutuações na "demanda efetiva"? [...] O que é toda a parte monetária de Industrial Fluctuations e da Theory of Unemployment de Pigou senão um estudo dos movimentos da “demanda efetiva?" (JMK, XIII, 1987, p. 504-505).

A insatisfação de Robertson com a recusa de Keynes em reconhecer a contribuição prévia de outros estudiosos dos ciclos econômicos tinha, por certo, fundamento. ${ }^{12}$ Em suas observações, ele poderia ter mencionado facilmente Wicksell, Fisher, Hawtrey, Hayek e até a si mesmo, para ficar em alguns poucos autores que haviam também formulado complexas teorias de como os bancos e o crédito atuavam sobre a demanda efetiva. Tanto assim que, ao descrever a congestão de visões concorrentes nesse campo específico durante os anos do entreguerras, Schumpeter avaliou o quadro como caracterizado por nada menos do que "discordância e esforço antagônico" (1963, p. 1.125), enquanto Blaug (1991), por sua vez, comparou-o a "um verdadeiro atoleiro de explicações conflitantes" ${ }^{13}$

Breve consulta às principais obras sobre os ciclos econômicos da era pré--keynesiana basta para evidenciar o papel essencial desempenhado pela demanda nas análises em voga no período. ${ }^{14}$ Uma ilustração conspícua é fornecida por Alfred Marshall, em Economics of Industry (1994 [1879]), quando ele delineia a mecânica do ciclo comercial, geralmente iniciada por boas colheitas que deprimiriam os preços dos alimentos e, assim, liberariam parte das rendas para serem gastas em outros artigos, cuja demanda correspon- 
dente aumentaria. Aproveitando-se do crédito fácil oferecido pelos bancos, os especuladores logo exacerbariam a onda favorável dos negócios, propelindo à frente a fase de prosperidade por meio da aquisição de estoques especulativos a serem vendidos a preços inflados em um futuro próximo. Marshall, inclusive, antecipa uma espécie de efeito propagação da demanda em sua vívida descrição da etapa ascendente do ciclo:

Os produtores percebem que a demanda por seus bens cresce; eles esperam vender com lucro e se dispõem a pagar bons preços pela entrega imediata do que precisam. Os empregadores competem entre si pela mão de obra; os salários sobem e os que se encontram empregados, ao despenderem seus salários, reforçam a demanda por todos os tipos de mercadorias (Marshall e Marshall, 1994 [1879], p. 152).

Em pouco tempo, o avanço desenfreado da especulação e do crédito aumentaria os custos em geral, tornando os investimentos mais dispendiosos, de sorte que novos empréstimos seriam requeridos para a conclusão dos projetos já iniciados. Em certo momento, porém, explica Marshall, as taxas de juros viriam a ser reajustadas para cima pelos credores mais cautelosos; a bolha especulativa explodiria e o movimento contrário de liquidação dos estoques e de deflação dos preços se instalaria em toda a economia (cf. Marshall, 1926 [1888], p. 51-52, passim, e Wolfe, 1970).

Já em Interest and Prices (1965 [1898]), Wicksell apresenta pela primeira vez o seu célebre Processo Cumulativo, situação abstrata de uma economia estacionária com concorrência universal e oferta elástica de crédito. Em tais condições, e assumindo uma posição inicial de equilíbrio entre poupança e investimento, qualquer escalada na procura de bens de capital seria rapidamente acomodada pelos bancos por meio de novos empréstimos a uma taxa de juros constante. Os empreendedores, isto é, os tomadores de capitais líquidos junto aos bancos, começariam a disputar mão de obra e outros recursos de produção, provocando uma alta nos rendimentos dos fatores e, por consequência, um acréscimo nos gastos:

Se os trabalhadores e os proprietários de terras elevam sua demanda por bens para o consumo do ano corrente na exata medida em que os salários monetários e as rendas em dinheiro cresceram, a demanda ampliada é satisfeita pelo mesmo volume anterior de capital na forma de mercadorias. Isso 
necessariamente resulta num aumento em todos os preços - um aumento que é simples considerar como proporcional ao avanço na demanda (Wicksell, 1965 [1898], p. 144, grifos do original).

Dado que os preços e as rendas teriam sido reajustados de forma equivalente, a taxa de lucro se manteria estável, de modo que no próximo período produtivo a demanda por empréstimos viria a crescer a fim de fazer frente ao nível mais elevado dos preços e custos. Tudo agora estaria no lugar devido para o início de uma nova rodada de inflação nos moldes vigentes no estágio anterior. Essa sequência de eventos, na concepção de Wicksell, poderia prosseguir indefinidamente, ao menos até que a taxa de juros fosse majorada de modo a cortar a procura de empréstimos, deflagrando, assim, a fase reversa do processo.

Os exemplos de tratamento da demanda efetiva como peça central nas teorias dos ciclos econômicos, notadamente durante o entreguerras, podem ser multiplicados à vontade. É suficiente para nossos propósitos apresentar aqui somente mais uma ilustração. Pigou, em Industrial Fluctuations (1967 [1927]), resgatara a maioria das contribuições passadas ao assunto, mas com ênfase no comportamento das expectativas. A natureza prospectiva das decisões de investimento e as oportunidades de crédito fornecidas pelo sistema bancário converteriam rapidamente um excesso de otimismo em uma demanda aumentada por mão de obra. Devido à longa gestação dos projetos de construção, no entanto, esclarece Pigou, os erros de prognóstico seriam descobertos apenas no instante em que o novo equipamento já estivesse em operação. Quando assim finalmente sucedesse, a prévia sensação de otimismo da fase de prosperidade se transformaria em um cenário pessimista em relação aos rendimentos futuros do capital, afetando a confiança dos negócios e abrindo caminho para a violenta liquidação dos ativos e dos estoques:

Sob a sua influência o moribundo erro de otimismo dá à luz a um erro de pessimismo. Esse novo erro não nasce uma criança, mas um gigante [...]. O erro de pessimismo assim estabelecido implica uma visão exageradamente depressiva por parte de todas as indústrias sobre a demanda futura por seus respectivos produtos emanada de outras indústrias. Em todas elas, portanto, verifica-se pouca atividade e a estagnação prevalece (Pigou, 1967 [1927], p. 92). 
Considerando então os antecedentes mencionados, alguns especialistas concluíram que os elementos fundamentais da GT já estariam presentes na literatura econômica antes de o livro vir a público. Em outras palavras, eles somente se encontravam dispersos nas obras do período até que Keynes habilmente os reunisse em uma única estrutura coerente. Essa, por exemplo, parece ser a opinião de Brigg após avaliar, de uma perspectiva lakatosiana, as contribuições dos principais economistas de Cambridge aos campos da moeda e dos ciclos nas primeiras décadas do século XX. O retrocesso observado à época na teoria do equilíbrio parcial dos mercados competitivos, segundo esse autor, teria sido motivado por um sério conflito existente no interior do programa de pesquisa marshalliano. No plano microeconômico, prevaleceria a racionalidade substantiva dos agentes, conducente ao equilíbrio de pleno emprego a longo prazo, enquanto no plano macroeconômico as decisões dos investidores estariam regidas por uma racionalidade comportamental, de onde proviriam as flutuações nos negócios ocasionadas pelos erros sucessivos de pessimismo e otimismo. Em meio a essa ambivalência, a teoria macroeconômica de Cambridge teria evidenciado um caráter progressivo nos escritos de Marshall e de seus sucessores, como Robertson e Lavington, culminando com a contribuição de Keynes, na qual diversos elementos da antiga ortodoxia estariam presentes. A diferença da GT em relação ao pensamento que lhe antecedeu, embora notável, seria fruto de uma evolução natural, consistindo na substituição dos preços pelas quantidades como componente de ajuste do sistema: "Em retrospecto, muito da cansativa luta de Keynes para escapar à tradição marshalliana pode ser visto como um programa contínuo de mudança e avanço teórico a partir daquelas mesmas raízes marshallianas” (Brigg, 1990, p. 192). ${ }^{15}$

Outro estudioso da escola de Cambridge, Bridel, desenvolveria ideia similar, mas de forma mais substantiva, ao indicar precisamente os pontos da GT vulneráveis à assimilação pela ortodoxia marshalliana, a saber, a explicação da taxa de juros mediante a preferência pela liquidez e o conceito de eficiência marginal do capital. Mais precisamente, a sugestão de Keynes de que a demanda especulativa por moeda $M_{2}$ dependeria da divergência entre a taxa de juros efetiva e certa taxa $r$ considerada segura pelo público haveria deixado indefinido esse valor referencial que, assim, poderia ser facilmente amarrado à taxa de juros "normal” estabelecida pelas funções poupança e 
investimento. Além do mais, o recurso de Keynes à curva de eficiência marginal do capital, de inspiração marshalliana, mantivera viva a ideia de que, apesar do conteúdo estritamente monetário da taxa de juros, continuaria a existir um valor único desta capaz de assegurar certa escala de investimento compatível com o pleno emprego. Daí haver subsistido a necessidade de Keynes explicar a divergência entre a taxa de juros efetiva e a nova taxa "normal”, justamente o foco das preocupações dos teóricos neoclássicos dos ciclos econômicos dos quais ele tanto fizera por se afastar. $\mathrm{Ou}$, como indicou Bridel a propósito desse segundo aspecto:

Obviamente, logo que adotou sua curva de demanda de investimento, restou a Keynes apenas uma saída para resgatar a validade do princípio da demanda efetiva: explicar as razões pelas quais a taxa de juros não convergiria para o seu nível "natural" de pleno emprego [...]. Além disso, essa via de escape era propensa a fornecer uma base sólida àquelas interpretações da General Theory [lideradas por Robertson e Hicks] que negavam a validade do princípio da demanda efetiva e reafirmavam o conceito marshalliano de uma taxa de juros "natural" como o centro de gravidade em direção ao qual tende a taxa de mercado (Bridel, 1987, p. 183-184).

Retornaremos a esse ponto na próxima seção. Antes, porém, é oportuno rememorar rapidamente a forma como os economistas neoclássicos pensavam o outro lado do problema do equilíbrio agregado, ou seja, a oferta total.

\section{O PRODUTO NA TEORIA NEOCLÁSSICA E O PRINCÍPIO DA DEMANDA EFETIVA}

Wicksell, cuja mecânica do processo cumulativo viria a inspirar diversas explicações do ciclo econômico nas primeiras décadas do século XX, incluindo o próprio Keynes do $T M$, assumiu ao longo de sua análise a constância do produto no nível de pleno emprego. Tanto que, em seu modelo básico, apenas os preços responderiam às variações na demanda. Como se pode ler em Interest and Prices:

É impossível subscrever a visão disseminada que sob condições apropriadas o produto de um país pode ser expandido quase indefinidamente pelo "recurso ao espírito empreendedor" e coisas do gênero. Essa visão falaciosa deriva do fato de se concentrar a atenção em único ramo de produção abaste- 
cido com um excesso de capital fixo (prédios, máquinas etc.). Em tal ramo de produção seria possível aumentar a oferta imediatamente, mas apenas em detrimento de outros ramos de produção dos quais trabalho e capital devem ser extraídos (Wicksell, 1965 [1898], p. 143, grifos do original).

Fisher, por sua vez, em The Purchasing Power of Money (1911), obra centrada no exame das perturbações transitórias da equação de trocas, relata como um acréscimo no estoque de ouro monetário geraria um aumento inicial de preços que terminaria por expandir os lucros em geral. Isso porque, segundo ele, a taxa de juros não se ajustaria automaticamente ao novo nível de preços, propiciando um ganho real suplementar aos homens de negócios que, assim, convergiriam aos bancos para ampliar seus empreendimentos por meio de novos empréstimos. O consequente aumento nos depósitos à vista realimentaria, então, o processo inflacionário original, até o instante em que a taxa de juros viesse a ser reajustada em magnitude superior à dos preços, dando início à fase reversa do ciclo. Tudo isso, porém, teria impacto preponderante sobre o nível de preços, afetando minimamente o produto:

Em épocas normais, praticamente toda a comunidade está envolvida em trabalhar, produzir, transportar e trocar os bens. $\mathrm{O}$ aumento da moeda num período de boom não pode, por si mesmo, aumentar a população, ampliar as inovações ou elevar a produtividade do trabalho. Tais fatores limitam definitivamente o volume de comércio que pode ser realizado. Assim, embora os ganhos do empresário-devedor possam fornecer um estímulo psicológico ao comércio [...], quase todo o efeito de um aumento nos depósitos se resumirá numa mudança de preços (Fisher, 1911, p. 62). ${ }^{16}$

Seja como for, é imediato que, ao se ingressar no campo das flutuações econômicas, a hipótese de "elasticidade nula do produto" deixava de ter utilidade. Pois o fenômeno cíclico nas sociedades industriais, especialmente nos anos do entreguerras, fora marcado não apenas por oscilações de preços e rendimentos, mas também por violentas comoções na produção e no emprego. O simples objetivo de formular uma teoria dos ciclos, portanto, fosse de cunho clássico ou heterodoxo, exigia que o comportamento volátil da oferta estivesse incluído, ao lado das variações na demanda, na moldura maior. E esse, em verdade, foi o caso com grande parte dos economistas de extração neoclássica nas primeiras décadas do século XX, como Cassel (1953 
[1924 ]), Robertson (1932 [1926]) e Pigou (1967 [1927]), que se ocuparam com as explicações dos altos e baixos do mundo dos negócios. Embora nenhuma interpretação comum de tais fenômenos viesse a ser compartilhada por esses autores, será conveniente aqui delinear-se a teoria de Robertson a esse respeito por ter sido ela uma das poucas a privilegiar os fatores reais como causadores dos ciclos econômicos.

Em Banking Policy and the Price Level (1932 [1926]), Robertson enumera os eventos que poderiam ocasionar descontinuidades justificadas ou racionais no fluxo da produção industrial. O primeiro deles consistiria nas variações nos custos reais. Tal tipo de flutuação apropriada no produto, seguindo o seu próprio léxico, poderia estar restrita a alguns setores da economia, como no caso de uma inovação específica, ou assumir caráter mais amplo, como durante as fases sucessivas do ciclo. Após certo tempo, já na depressão, tanto os ganhos na produtividade do trabalho quanto na reorganização geral da produção causariam uma expansão na oferta, enquanto nos estágios finais do boom o uso intensivo da mão de obra e a administração leniente reduziriam o ritmo de crescimento de produto. Além disso, inovações de amplo espectro, como as ferrovias, a energia elétrica e o motor a diesel, tenderiam a intensificar o desejo de investir em tais equipamentos até o ponto de saturação temporária ser atingido. Outras forças em operação causadoras de oscilações na oferta compreenderiam a volatilidade das colheitas agrícolas e a queda de preço nos materiais de construção, esta última beneficiando largos segmentos da economia (Robertson, 1932 [1926], p. 6-18).

Além disso, Robertson menciona, ainda, outros elementos que tenderiam a amplificar as oscilações naturais na oferta agregada. Entre tais flutuações inapropriadas do produto inscrevia-se a indivisibilidade de alguns tipos de equipamento que exigiriam grandes saltos na capacidade produtiva, ultrapassando o limite recomendável pelo crescimento efetivo da demanda. Adicionalmente, a pressão competitiva para atender a uma procura mais intensa poderia induzir cada firma a expandir sua produção sem qualquer informação sobre a iniciativa similar de seus rivais, de modo que esses esforços desordenados terminariam por fazer a oferta extravasar o montante rentável garantido pelo mercado. Simultaneamente, a influência psicológica mútua entre os industriais aceleraria a rápida difusão dos voláteis estados mentais sobre a saúde geral dos negócios, criando, assim, ondas de confian- 
ça e de descrédito na economia. E, finalmente, os produtores poderiam superestimar a magnitude da expansão na demanda indicada por um aumento no seu preço de venda se não prestassem atenção devida à alta paralela nos custos, o que tenderia a induzi-los a aceitar uma escala de produção maior do que a apropriada (Robertson, 1932 [1926], p. 34-39).

Após esse rol de oscilações no produto, em linha com o admitido por outros economistas do período (notadamente Pigou, 1967 [1927], Parte I), é imperativo rejeitar a tese de Keynes de que os economistas "clássicos" assumiam a economia como estando invariavelmente no nível de pleno emprego. Em que pese, porém, a visão atilada das condições de oferta por parte de vários autores do período, nem Robertson, nem tampouco seus contemporâneos foram capazes de fazer uso operacional de tais intuições em um plano teórico mais elevado. Para Pigou, Cassel, Hayek e outros economistas do entreguerras, o ciclo econômico era interpretado, em geral, como sintoma de algum desequilíbrio velado, nascido de uma desproporção entre poupança e investimento sancionada ou até mesmo deflagrada pela política de crédito fácil por parte do sistema bancário. Quando se impunha analisar os caminhos pelos quais tais distúrbios afetavam a economia no seu conjunto, eles comumente raciocinavam em termos das forças capazes de impulsionar ou reverter as diversas fases do trajeto cíclico do produto em torno do seu nível de pleno emprego. ${ }^{17}$

Um exemplo do desajuste cíclico contemplado pelos autores neoclássicos pode ser representado por uma intensificação mais ou menos abrupta no desejo de investir financiada pelo sistema bancário à taxa de juros vigente. $\mathrm{O}$ equilíbrio da economia, contudo, não estaria irremediavelmente comprometido devido à ação, algumas vezes simultânea, de três mecanismos: (a) pela privação forçada imposta aos detentores de rendimentos fixos, como admitido por Hayek e outros. Esse efeito coincidiria com aquilo que Robertson denominou "restrição automática" (automatic stinting), a ter lugar "sempre que um aumento na corrente de dinheiro dirigida ao mercado impede certas pessoas de consumir os bens que elas, de outra maneira, haveriam consumido" Robertson (1932 [1926], p. 47); ${ }^{18}$ (b) pelo abandono dos novos planos de investimento em virtude da carência de recursos reais para a sua consecução ou pelo desmoronamento tardio das expectativas. A reversão da fase de prosperidade e a erupção da crise, de acordo com Cassel, por exem- 
plo, sucederiam inexoravelmente porque os investidores, como regra, tendiam a superestimar a oferta de recursos reais livres: “[...] virá um tempo quando se torna claro que o mercado não encontra poupança para a aquisição dos bens de capital em quantidades suficientes. Terá vez então uma queda súbita no valor do capital real e os empregadores acharão extremamente difícil obter o capital que precisam" Cassel (1953 [1924], p. 126). E, finalmente, (c) por um aumento diferido e repentino da taxa de juros quando a demanda por crédito estivesse escapando do controle dos bancos devido à especulação e ao aumento nos preços dos bens de capital. Como escreveu Marshall: "Os detentores de capital [livre (free)] já pretendem contrair seus empréstimos e a demanda por mais financiamentos eleva a taxa de juros demasiadamente. A desconfiança cresce, os credores tornam-se ansiosos para garantir seus ganhos e recusam-se a renovar os empréstimos em termos fáceis ou mesmo em qualquer outro" (Marshall, 1929 [1923], p. 250).

Em suma, as alternativas (a) e (b) corresponderiam, respectivamente, a deslocamentos nas curvas de oferta de abstinência e de procura de capital que rebaixariam a taxa "natural" ao seu patamar pretérito, nivelando-a novamente à taxa de juros efetiva, enquanto a alternativa (c) implicaria o movimento reverso. Tais seriam as forças capazes de eliminar o hiato entre as taxas de juros "real" e "monetária", imprimindo ao produto oscilações de tipo pendular em torno do seu nível de pleno emprego.

Nesta altura, a discussão teórica anterior pode ser sumarizada da seguinte maneira: para os economistas neoclássicos, o problema do ciclo, e de todo desequilíbrio econômico a ele associado, originava-se no fato de um aumento (ou redução) no gasto acontecer em certo ponto do sistema econômico sem uma redução (ou aumento) correspondente da despesa em outro ponto qualquer. Esse tipo de raciocínio foi inequivocamente apontado por Keynes, embora em termos agregados, em correspondência a Hawtrey, no mês de abril de 1936:

Não estou seguro se o que segue não é a melhor definição de pleno emprego no meu sentido: "Existe uma situação aquém do pleno emprego se a propensão a consumir sendo assumida como constante, um aumento no investimento ocasiona um aumento no consumo." Contra isso, a suposição normal da teoria clássica é que uma expansão no investimento deve (ou deverá) envolver um decréscimo no consumo (JMK, XIV, 1973, p. 26, grifo do original). 
Sob o prisma enunciado, a generalidade da teoria de Keynes em face da economia neoclássica pode ser facilmente apreendida. Sua divisão da demanda em gastos de consumo e de investimento permitiu-lhe conceber os dois conceitos gêmeos de propensão marginal a consumir (PMC) e de propensão marginal a investir $(P M I),{ }^{19}$ de modo que o princípio da demanda efetiva admitiria expressão por meio da desigualdade $P M C+P M I<1$. A propensão a investir, contudo, terminaria por ser abandonada na versão final da GT, provavelmente por insinuar uma relação entre investimento e renda mais estável do que Keynes estaria disposto a admitir. ${ }^{20}$ Não obstante, ao comentar o que julgava ser o principal problema econômico das sociedades afluentes, assinalou ele que o declínio da propensão a consumir, à medida que a renda crescia, representava um estreitamento das oportunidades de investimento que faria por ampliar o lapso entre o produto potencial e a demanda efetiva. $O$ resultado inevitável de tal dificuldade, considerando-se uma economia organizada sob o princípio da livre concorrência, seria um volume de produção aquém do pleno emprego, independentemente da situação experimentada pelos mercados de fatores: "Essa análise nos fornece uma explicação para o paradoxo da pobreza em meio à fartura. Pois a mera existência de uma insuficiência de demanda pode e comumente poderá provocar a estabilização do emprego antes que o nível de pleno emprego tenha sido atingido" (GT, 1964 [1936], p. 30-31). Como resumiu apropriadamente Kohn:

Antes da General Theory, a análise monetária neoclássica esteve ocupada com a estabilidade do sistema econômico em torno do equilíbrio [...]. A adoção do método do equilíbrio por Keynes exigiu-lhe, como requisito de consistência lógica, o abandono dessa visão do objeto da análise real e monetária. Sua nova teoria descrevia uma situação que não apenas diferia do equilíbrio da análise real, mas que também se constituía em si mesma um equilíbrio. Ou seja, não poderia existir tendência do equilíbrio de Keynes retornar ao equilíbrio padrão da análise real. Se essa tendência existisse, seu equilíbrio não poderia ser considerado como tal, e todo o seu método de análise estaria comprometido (1986, p. 1.213, grifos do original).

Contrariamente à posição de Keynes, não só os economistas clássicos, mas especialmente os neoclássicos em particular assumiam a condição $P M C$ $+P M I=1$ como norma de estabilidade da economia, no que podemos cha- 
mar aqui de "princípio da compensação". Sempre que tal condição fosse violada, a economia passaria a um estado de desequilíbrio, percorrendo uma rota de expansão ou de retrocesso a ser revertida pela ação automática dos mecanismos descritos anteriormente. A versão mais articulada da abordagem teórica neoclássica amparada no "princípio da compensação" durante os anos do entreguerras seria desenvolvida em The Theory of Unemployment (1968 [1933]), de Pigou. Na quarta parte de seu livro, cujo objetivo era oferecer uma investigação metódica dos determinantes do emprego a partir das perspectivas real e monetária, ele concebe um "sistema monetário padrão" abstrato com o propósito exclusivo de prover a economia com um tipo de moeda neutra sob a qual cada transação econômica prosseguiria como se ela não existisse. Sistemas monetários concretos, porém, observa Pigou, não garantiriam a estabilidade econômica, por falharem usualmente em reproduzir a taxa de juros "apropriada", ou seja, aquela que ajustaria as necessidades de capital real por parte dos industrialistas à oferta disponível de poupança. A incapacidade da comunidade bancária em replicar tal condição hipotética, segundo o professor, estaria na raiz da maior parte das perturbações no mercado de trabalho e, consequentemente, do agravamento da intensidade dos ciclos econômicos nascidos de causas reais, como modificações na demanda, no custo das matérias-primas ou na produtividade do trabalho. Logo, a estabilidade econômica, ao menos da perspectiva estritamente monetária, exigiria o restabelecimento do "princípio da compensação", ou, nas palavras do próprio Pigou:

A fim de que a renda monetária varie na devida proporção [...] com as variações na quantidade dos fatores de produção em uso, os industrialistas, nos tempos de boom, devem apenas obter dinheiro para empregar mais mão de obra, na medida em que eles e as pessoas de quem tomam emprestado se abstenham de gastar dinheiro em bens-salário e em bens não salariais importados [obtidos pela exportação de bens-salário] e, de maneira similar, em tempos de depressão, à medida que os industrialistas investem menos dinheiro no emprego do trabalho, eles ou outras pessoas devem gastar de forma correspondente mais dinheiro em bens-salário e bens não salariais importados (1968 [1933], p. 211).

Keynes deixaria explícita sua posição discordante com relação a tal espécie de raciocínio na já mencionada carta de 13 de dezembro de 1936 ende- 
reçada a Robertson. Na oportunidade, ele reforçou sua ideia de que a oferta viável de bens de consumo dependeria da magnitude dos bens de capital sendo produzidos, de sorte que ambas as variáveis se moveriam na mesma direção conforme o multiplicador. Além do mais, esse movimento conjunto, ao invés de apresentar-se como um sintoma de desequilíbrio, deveria ser considerado como o autêntico processo de estabelecimento de um novo equilíbrio para a economia. Na forma em que Keynes colocou a questão:

A quantidade a ser consumida depende da quantidade de renda gerada [na produção]. Assim, a quantidade de consumo que induzirá os empresários a produzir depende da quantidade de bens de investimento que eles estejam a produzir. Se, por exemplo, o público tem o hábito de gastar nove décimos de sua renda em bens de consumo, segue que se os empresários fossem produzir bens de consumo a um custo maior do que nove vezes o custo dos bens de investimento que eles se encontram produzindo, alguma parte de seu produto não poderia ser vendida a um preço que cobrisse seu custo de produção (JMK, XIV, 1973, p. 90). ${ }^{21}$

É preciso, por fim, dar conta da crítica de Bridel apresentada nos parágrafos anteriores. Para ele, como visto, a debilidade da teoria de Keynes assentava-se na indeterminação da taxa de juros referencial que regularia o componente especulativo da preferência pela liquidez, bem como na adoção da curva marshalliana de eficiência marginal do capital. Ambas as dificuldades, contudo, podem ser devidamente aquilatadas quando se tem presente que a pertinência das duas apoia-se crucialmente na suposição de rigidez da curva de eficiência marginal do capital. Pois essa é a condição teórica indispensável para a existência de uma taxa de juros "natural” única, seja em seu sentido real ou neoclássico, seja em seu sentido monetário ou keynesiano. Nada, porém, mais apartado da concepção de Keynes do que uma curva de procura de capital fixa e imutável, sabendo-se ser ela formada pelas expectativas sobre os rendimentos prospectivos de longo prazo dos possíveis investimentos e sujeitas, portanto, a todo tipo de influências e modificações. "O erro de se considerar a eficiência marginal do capital principalmente em termos do rendimento corrente do equipamento de capital, que seria correta apenas no estado estático onde não existisse futuro para influenciar o presente, tem como resultado a ruptura do elo teórico entre o hoje e o amanhã”, esclareceu Keynes na GT, ao que aduziu: “O fato de que os pressupos- 
tos do estado estático geralmente embasem a teoria econômica moderna confere-lhe um largo elemento de irrealismo" (GT, 1964 [1936], p. 146). Assim, se ao invés de uma única curva de eficiência marginal existirem várias delas, cada qual dependente de um dado estado de confiança no futuro, então a taxa de juros "natural", qualquer que seja o seu significado, deixa de ter relevância teórica por se transformar de uma em muitas, fazendo a recuperação marshalliana de Keynes divisada por Bridel perder grande parte de sua consistência.

\section{CONSIDERAÇÕES FINAIS}

Tanto os antigos pensadores clássicos quanto os dissidentes, apesar de suas motivações distintas, compartilhavam a noção de que a poupança e o investimento coincidiriam invariavelmente, divergindo a partir daí a respeito das consequências dessa igualdade para o desempenho da economia no seu todo. Os economistas neoclássicos anteriores a GT, porém, raciocinavam em bases distintas, admitindo eventual descompasso entre a oferta de abstinência e a procura de capital líquido, mostrando criatividade quase ilimitada na concepção de formas alternativas de igualação posterior da poupança com o investimento. Apesar de sua engenhosidade, nenhum deles conseguiu elaborar resposta satisfatória à necessidade de integração entre as teorias dedicadas aos determinantes da procura e da oferta na esfera agregada. Keynes, por meio do princípio da demanda efetiva, expresso na desigualdade $P M C+$ $P M I<1$, logrou submeter ao domínio da ciência econômica todas as possibilidades de produção inferiores ao pleno emprego, enquanto, ao mesmo tempo, por meio do multiplicador, definia um valor específico do produto como a única combinação na oferta de bens de consumo e de investimento capaz de atender à demanda agregada. Nesses fundamentos, em síntese, apoiou-se a abordagem de Keynes, a qual ele acreditava conformar-se melhor à realidade do capitalismo de seus dias, como Marshall convidara os economistas a proceder quatro décadas antes.

É compreensível, ainda, que, ao se revisar a literatura econômica sobre a moeda e os ciclos à época de Keynes, seja tentador decodificar suas ideias em termos de outras já trabalhadas nas obras dos autores que o antecederam. A verdadeira extensão de seu aporte à teoria econômica da época constitui-se 
em alvo de discussão perene entre os especialistas e para a qual o presente artigo não pretende oferecer solução. Sobre isso, contudo, vale mencionar que o próprio Keynes jamais negou a herança intelectual recebida da escola clássica que viria a combater. Em correspondência a Hawtrey, ao final de 1935, ele reconhece o débito com seus predecessores quando explica os fatores determinantes das decisões de investimento, em oposição ao hábito do amigo de pensar a acumulação de capital unicamente por meio do impacto das vendas sobre o volume de estoques: "Mas isso não é o que Marshall ou Pigou ou a maioria dos economistas modernos fazem. A demanda que determina as decisões sobre quanto utilizar do equipamento deve relacionarse necessariamente com as expectativas. $\mathrm{E}$ eu, nesse aspecto, simplesmente tento colocar com maior precisão o que está implícito em grande parte da economia contemporânea" (JMK, XIII, 1987, p. 602). Alguns meses antes, Keynes escrevera a Harrod, no mesmo sentido, que o verdadeiro objetivo da GT não era somente atacar a ortodoxia econômica, mas também prestar tributo aos antigos hereges, invariavelmente desprezados por apontarem a incongruência da visão clássica com a realidade capitalista que ela deveria representar:

O que pretendo é fazer justiça às escolas de pensamento que os clássicos trataram como imbecis ao longo dos últimos cem anos e, acima de tudo, mostrar que não sou de fato um grande inovador, salvo no tocante à escola clássica, mas que tive importantes predecessores e que retorno a uma longa tradição de senso comum (JMK, XIII, 1987, p. 552).

\section{NOTAS}

1. Samuels, algum tempo atrás, compilou as seguintes definições da escola neoclássica constantes na literatura pertinente: (i) a teoria subjetiva da utilidade marginal de 1870 em diante; (ii) a teoria econômica de Alfred Marshall; (iii) os trabalhos dos autores do século XX seguindo a tradição de Marshall ou Walras; (iv) alguma combinação do item anterior; (v) a síntese neoclássica, inspirada em Samuelson, aglutinando, de uma parte, a maximização na alocação de recursos sob restrição e, de outra, a macroeconomia keynesiana (Hennings e Samuels, 1990, p. 1-12). Nenhuma dessas possibilidades inclui os economistas clássicos anteriores a 1870.

2. O termo voltaria a ser mencionado mais tarde em uma única oportunidade, em carta a Hawtrey, datada de abril de 1936, na qual consta o seguinte fragmento: "Entendo por escola clássica, como expliquei várias vezes, não apenas Ricardo e Mill, mas Marshall e 
Pigou e Henderson e a mim mesmo até recentemente, e de fato todos os professores do assunto neste país, excetuando você e algumas poucas figuras como Hayek, a quem me refiro como neoclássicos" (JMK, XIV, 1973, p. 24, grifo do original).

3. Para as dezenas de entradas associadas ao termo clássico listadas nos índices da GT e dos volumes XIII e XIV das obras de Keynes, veja-se GT (1964 [1936], p. 385-403) e JMK (XIV, 1973, p. 529-584).

4. O próprio Keynes admite, no capítulo 19, que tal sequência de eventos, ligando as variações nos rendimentos à taxa de juros e ao investimento, não fora contemplada em momento algum pelos economistas clássicos (GT, 1964 [1936], p. 266).

5. Esse resultado, cumpre notar, não seria devido apenas ao fato de os acordos fixarem os salários em termos nominais, mas também às conexões entre nível dos salários nominais, demanda efetiva, preços e, por fim, os salários reais. Keynes, quando trata o assunto de forma mais aprofundada, no capítulo 19, admite a possibilidade de um corte no salário nominal conduzir (por meio de um mecanismo complexo envolvendo as variáveis mencionadas) a um aumento no emprego, o qual, para ele, implicaria uma queda do salário real.

6. Embora, por indicação de Harrod, tenha sido incluído um gráfico na GT representando a poupança como função positiva da taxa de juros, Keynes parece nunca haver se convertido inteiramente à ideia, como ele deixaria explícito em uma carta a Kaldor, em outubro de 1937: "Minha hipótese normal é que $d S / d r$ seja negativa [...]. O ponto é que uma redução na taxa de juros, acresça ela ou não a propensão a consumir calculada para uma renda dada, aumenta o volume absoluto de poupança devido ao seu efeito sobre a renda via o estímulo do investimento" (JMK, XIV, 1973, p. 243).

7. Keynes observa ainda a esse respeito que a proposta de certos autores neoclássicos, como Robertson (1932 [1926], p. 76-77), de majoração dos juros ao início da fase de prosperidade a fim de evitar o descompasso entre poupança e investimento e a consequente inflação, seria igualmente absurda. "O remédio correto para o ciclo econômico não reside em erradicar as expansões e preservar de forma permanente uma semiestagnação, mas em abolir as depressões e manter de forma permanente um estado de quase boom" (GT, 1964 [1936], p. 322).

8. Em meio ao seu pronunciamento, Keynes esclareceu aos ouvintes que a doutrina marxista consistiria apenas em uma variante da ortodoxia do século XIX: "Na verdade, o marxismo é uma inferência altamente plausível da economia ricardiana que proclama a impossibilidade de o capitalismo individualista funcionar na prática. Tanto que, se a economia ricardiana viesse a sucumbir, um suporte essencial dos fundamentos intelectuais do marxismo sucumbiria com ela" (JMK, XIII, 1987, p. 488).

9. O medo das mercadorias, como descreve Hecksher, encontrava voz na atenção constante dos mercantilistas com a venda da produção doméstica no âmbito de uma economia monetária, quando a finalidade última da atividade econômica já assumira a forma de dinheiro. A criação de oportunidades de ocupação dentro do país aparecia como corolário desse princípio maior, embora não se considerasse recomendável que os trabalhadores recebessem salários elevados a fim de não comprometer seu empenho laboral. 
O aumento da circulação monetária, por sua vez, além do barateamento dos juros destacado por Keynes, deveria fomentar a produção ao elevar o preço pago aos produtores nacionais (Hecksher, 1943 [1931], p. 561-618).

10. O termo neoclássico, nesta seção e no restante do artigo, compreende não apenas os autores mencionados por Keynes, mas também Marshall e Pigou.

11. Isso, é claro, se Stuart Mill for deixado fora do quadro, uma vez ter sido ele o único, durante o período clássico, capaz de defender a Lei de Say ao refutar os apelos em favor do gasto das classes aristocráticas e do governo, ao mesmo tempo em que defendia uma refinada teoria das crises comerciais baseada nas flutuações do crédito induzidas pelo comportamento especulativo dos devedores, nos moldes sugeridos por Thomas Tooke (Link, 1959; Forget, 1990).

12. Robertson possuía grande familiaridade com o assunto por haver redigido a tese A study in industrial fluctuations, em 1914, publicada no ano seguinte, na qual examinava inclusive a literatura continental sobre os ciclos econômicos (cf. Presley, 1979, Parte I).

13. Em que pese o estado de efervescência entre teorias conflitantes, Haberler (1936) identificou uma linha comum em todas as tentativas de explicação da recorrência dos ciclos durantes os anos 1930, a saber, que a natureza cumulativa do desequilíbrio econômico originava-se no fato de os bancos fixarem sua taxa de juros dos empréstimos independentemente da taxa "natural" ou "normal" determinada pela intersecção das curvas de oferta e de demanda por fundos líquidos, ideia que mais tarde Leijonhufvud (1979) designaria por "conexão Wicksell” (veja-se, a esse respeito, Laidler, 1998).

14. Extensa revisão da literatura pertinente pode ser encontrada em Haberler (1946), Hansen, (1964), Bridel, (1987), Brigg (1990) e Laidler (1999).

15. Essa não é uma opinião isolada. Laidler, apoiado em uma revisão mais ampla da literatura dos ciclos no entreguerras, afirmou: "Antes, ela [a economia de Keynes] sintetizou e permitiu um debate ordenado sobre questões que, longe de serem revolucionárias no sentido de superarem o que veio antes, tinham de fato permeado as complexas discussões sobre a moeda, o ciclo e o emprego que tiveram lugar nos anos seguintes à Primeira Guerra Mundial” (Laidler, 1999, p. 4). Mais recentemente, De Vroey, em sua reavalição crítica da teoria do desemprego contida na GT a partir do modelo de mercado competitivo de Marshall, concluiu que, "[...] exceto por esse pressuposto [a rigidez salarial], as diferenças entre a demanda efetiva à la Marshall e a demanda efetiva à la Keynes são mínimas" (2009, 1).

16. A mesma suposição é encontrada em The Economics of Industry (1998 [1879], p. 18), de Marshall, assim como no artigo "Capital and industrial fluctuations" (1934), de Hayek, e até mesmo na análise dos lucros elaborada por Keynes em sua alegoria do jarro da viúva (widow's cruse) no TM (1971 [1930], p. 125), criticada mais tarde por Robinson (1933) em razão de desconsiderar a possibilidade de variações de curto prazo na oferta em resposta ao estímulo da demanda.

17. Na descrição de Kohn, ao comentar o renascimento da análise monetária no entreguerras: "O seu ponto de partida [dos teóricos dos ciclos] era o equilíbrio real da análise clássica e neoclássica. Acreditava-se que a economia de fato se desviava desse ideal porque os choques reais ou monetários poderiam deslocar a economia ou o equilíbrio em 
si. Enquanto o véu monetário poderia ser confortavelmente ignorado ao caracterizar-se a natureza do equilíbrio, os fatores monetários eram essenciais à compreensão do movimento da economia na direção ou em torno do equilíbrio” (Kohn, 1986, p. 1.197).

18. O processo contrário, em presença de uma maior inclinação a poupar, daria origem ao que Pigou denominou "poupança abortiva" em virtude do inevitável barateamento dos bens de consumo: "Sua conduta [do poupador] faz por reduzir ligeiramente os preços em geral, mas não conduz, como ele tencionava, a nenhuma poupança real” (Pigou, [1967] 1927, p. 147).

19. No rascunho da GT, de 1934, Keynes denota o que chamou de propensão a gastar por $C_{w}=f_{1}(N, r, E)$ e propensão a investir por $I_{w}=f_{2}(N, r, E)$, sendo $N$ o emprego, $r$ a taxa de juros e $E$ o estado de expectativas de longo prazo. Ele indicou as variações no primeiro componente da demanda por $\Delta C_{w}=d f_{1}(N) / d N$, o que nos permite escrever, por analogia, $\Delta I_{w}=d f_{2}(N) / d N$ para a propensão marginal a investir (JMK, XIII, 1987, p. 439-459).

20. Discutindo com Harrod a possibilidade de existência de uma taxa "garantida" de crescimento da economia, calculada por meio do multiplicador e da "relação", espécie de acelerador, Keynes, em abril de 1937, escreveu: "Até aqui, excluímos a possibilidade de mudanças nas expectativas. De fato, porém, a taxa de investimento não depende do consumo corrente, mas das expectativas (embora essas últimas sejam influenciadas, é claro, talvez indevidamente, pelo consumo corrente). Assim, a menos que as expectativas sejam de uma natureza constante, seria de se antecipar mudanças de curto prazo na relação" (JMK, XIV, 1973, p. 172).

21. Em uma resenha da GT raramente mencionada, de junho de 1936, Hicks considera exatamente esse aspecto como a marca singular da teoria do emprego de Keynes: "No fim das contas, é deveras importante observar a parte essencial desempenhada no argumento de Mr. Keynes - ou seja, em sua teoria de como os bens de consumo se ajustam a uma mudança nas expectativas de longo prazo - pela suposição de uma alta elasticidade da oferta de bens de consumo. Enquanto essa hipótese se justificar, o argumento é, no seu todo, aceitável; e não há dúvida de que ele seja quase sempre justificado" (Hicks, 1936, p. 245).

\section{REFERÊNCIAS BIBLIOGRÁFICAS}

BECKER, G. S.; BAUMOL, W. J. The classical monetary theory: the outcome of the discussion. In: SPENGLER, J. J; ALLEN, W. A. (Orgs.). Essays in Economic Thought: Aristotle to Marshall. Chicago: Rand McNally, 1960. p. 753-771.

BLAUG, M. Ricardian Economics. A Historical Study. Nova Haven: Yale University Press, 1958. Second thoughts on the Keynesian Revolution. History of Political Economy, v. 23, n. 2, p. 171-92, 1991.

BLEANEY, M. Underconsumption Theories. Nova York: International Publishers, 1976.

BRIDEL, P. The Development of Saving-investment Analysis from Marshall to Keynes. Cambridge Monetary Thought. Nova York: St. Martin's Press, 1987.

BRIGG, R. J. Cambridge and the Monetary Theory of Production. The Collapse of Marshallian Economics. Nova York: St. Martin's Press, 1990. 
CASSEL, G. The determining factors of conjuncture-movements. In: HANSEN, A. A; CLEMENCE, R. V. (Orgs.). Readings in Business cycles and National Income. Nova York: W. W. Norton, 1953 [1924]. p. 116-128.

CORRY, B. A. Money, Saving and Investment in English Economics 1800-1850. Nova York: St. Martin's Press, 1962.

DE VROEY, M. The Marshallian roots of Keynes's General Theory. Discussion Paper, Institut de Recherches Économiques et Sociales, Université Catholique de Louvain, n. 27, 2009.

FISHER, I. The Purchasing Power of Money. Nova York: Macmillan, 1911.

FORGET, E. L. John Stuart Mill's business cycles. History of Political Economy, v. 22, n. 4, p. 629-642, 1990.

HABERLER, G. Some reflections on the present situation of business cycles theory. The Review of Economic Statistics, v. 18, n. 1, p. 1-7, 1936.

Prosperity and Depression. Nova York: United Nations, 1946.

HANSEN, A. H. Business Cycles and National Income. Nova York: W. W. Norton, 1964.

HAYEK, F. von. Capital and industrial fluctuations. Econometrica, v. 2, n. 2, p. 152-67, 1934.

HECKSHER, E. F. La Epoca Mercantilista. México: Fondo de Cultura Economica, 1943 [1931].

HENNINGS, K; SAMUELS, W. (Orgs.). Neoclassical Economic Theory, 1870 to 1930. Boston: Kluwer Academics, 1990.

HICKS, J. R. Keynes' theory of employment. The Economic Journal, v. 46, n. 182, p. 238-253, 1936.

KEYNES, J. M. The Collected Writings of John Maynard Keynes (JMK), v. 1: A Treatise on Money; v. V: The pure theory of money. Londres: Macmillan for the Royal Economic Society, $1971[1930]$.

—. Essays on Biography. Nova York: W. W. Norton, 1951 [1933].

. The General Theory of Interest, Employment and Money. Nova York: Harcourt Bruce Jovanovich, 1964 [1936].

KOHN, M. Monetary analysis, the equilibrium method and Keynes's General Theory. The Journal of Political Economy, v. 94, n. 6, p. 1.191-1.224, 1986.

LAIDLER, D. The Wicksell connection, the Quantity Theory and Keynes. Studien zur Enwincklung der Ökonomischen Theorie, XVIII. Berlin: Duncker \& Humblot, 1998.

Fabricating the Keynesian revolution. Studies of the Inter-war Literature on Money, the Cycle and Unemployment. Cambridge: CUP, 1999.

LEIJONHUFVUD, A. The Wicksell connection. Working Paper, Ucla, Department of Economics, n. $165,1979$.

LINK, R. G. English theories of economic fluctuations 1815-1848. Nova York: Columbia University Press, 1959.

MARSHALL, A. Official Papers by Alfred Marshall. Londres: Macmillan for The Royal Economic Society, 1926 [1888]. 
The old generation of economists and the new. In: PIGOU, A. C. (Org.) Memorials of Alfred Marshall. Londres: Macmillan, 1925 [1896]. p. 295-311.

Money credit and commerce. Londres: Macmillan, 1929 [1923].

MARSHALL, A.; MARSHALL, M. P. The economics of industry. Bristol: Thoemmes Press, 1994 [1879].

MOOGRIDGE, D. (Org.). The Collected Writings of John Maynard Keynes (JMK), V. XIV: The General Theory and after. Part II. Defence and development. Londres: Macmillan for The Royal Economic Society, 1973.

. The Collected Writings of John Maynard Keynes (JMK), V. XIII: The General Theory and after. Part I. Preparation. Londres: Macmillan for The Royal Economic Society, 1987.

PIGOU, A. C. Industrial Fluctuations. Londres: Frank Cass, 1967 [1927].

. The Theory of Unemployment. Londres: Frank Cass, 1968 [1933].

PRESLEY, J. R. Robertsonian Economics. Nova York: Holmes and Meier, 1979.

ROBertson, D. H. Banking Policy and the Price Level. Londres: P. S. King \& Son, 1932 [1926].

\section{1.}

ROBINSON, J. A parable on saving and investment. Economica, n. 39, p. 75-84, 1933.

SCHUMPETER, J. A. History of Economic Analysis. Londres: George Allen \& Unwin, 1963.

SOWELL, THOMAS. Say's Law. An Historical Analysis. Ewing: Princeton University Press, 1972.

WICKSELL, K. Interest and Prices. Nova York: Augustus M. Kelley, 1965 [1898].

WOLFE, J. N. Marshall and the trade cycle. In: RIMA, I. (Org.). Readings in the History of Economic Theory. Nova York: Holt, Rinehart and Winston, 1970. p. 154-163. 